\title{
Mobile healthcare: Perspectives in Russia
}

\author{
Sergey M. Avdoshin \\ Professor, Head of Software Engineering School \\ National Research University Higher School of Economics \\ Address: 20, Myasnitskaya Street, Moscow, 101000, Russian Federation \\ E-mail: savdoshin@hse.ru
}

\section{Elena Yu. Pesotskaya}

Associate Professor, Software Engineering School

National Research University Higher School of Economics

Address: 20, Myasnitskaya Street, Moscow, 101000, Russian Federation

E-mail:epesotskaya@hse.ru

\begin{abstract}
This paper analyses the possibility of using mobile technologies and applications in the Russian healthcare system and evaluates the opportunities for its further development. The research provides an overview of global trends in digital healthcare with some examples of the best solutions for eHealth (healthcare practice supported by electronic processes and communication). An analysis is made of the Russian medical system in order to identify the main stages of its formation, achievements and areas for improvement. The authors also conducted research into the current Russian medical healthcare system aimed at identifying gaps and concerns regarding security, reliability and service availability for on-line and mobile services and personal health records in Russia. Certain difficulties in the establishment of an up-to-date healthcare system in Russia with examples of barriers are also analyzed to get a better understanding of the prospects for mobile healthcare development. Starting from the premise that support for information technologies is essential to medical healthcare development, the paper gives an overview of the current IT initiatives of the Russian government in the field of medicine and provides examples of the independent applications of Russian software developers for digital and mobile healthcare. As a result of the research, three possible development scenarios of Russian mobile healthcare are described. The barriers identified as well as worldwide healthcare transformation aspects such as cost reduction and personalization are considered in the possible scenarios.
\end{abstract}

Key words: healthcare system, mobile healthcare, IT health monitoring, personal health records, medical information system, mobile services, information technologies.

Citation: Avdoshin S.M., Pesotskaya E.Yu. (2016) Mobile healthcare: Perspectives in Russia. Business Informatics, no. 3 (37), pp. 38-44. DOI: 10.17323/1998-0663.2016.3.38.44.

\section{Introduction}

A ccording to global trends, the world population is becoming more dependent on healthcare services due to natural aging. By 2030 over 37 million people will suffer from at least one chronic condition, 14 million will be suffering from diabetes; half will have arthritis and more than one-third or over 21 million, will be classified as obese [1]. Similar problems exist across the developed world. The number of healthcare professionals is decreasing in many countries, and this is becoming a real problem for maintaining health. In this situation, due to a shortage of traditional medical care, people tend to turn to modern IT services and technologies, searching the Internet and their smart devices for tips on how to behave in this or that situation.

Mobility in healthcare means leveraging healthcare and information technologies to provide a different kind 
of services - from using mobile networks as a means of providing information at the most basic level, to complete diagnosis and consultation at the most sophisticated stage, including patient record keeping, applications and keeping track of the individual's medical history. These days, global medicine can monitor health issues with "intelligent shirts" through electrodes, use sensors to monitor patients' vital signs, activity sensors and webcams. It is not a regular service available to everyone, but it is part of a trend that will continue to grow in the near future. A large number of applications - from handheld devices to facilitate remote diagnosis to touchscreen technologies and "smart" devices will facilitate remote monitoring and communication. It is absolutely true that healthcare is moving away from paper-based files toward electronic medical records, though in Russia still many people, mostly from the Soviet generation, do not trust their diagnoses and treatment, unless they are printed out. In addition, many doctors from public clinics think they cannot communicate properly with their patients unless they get everything down on paper.

Some medical experts consider that the primary goal of mobile healthcare (mHealth) [2] is to get information from one location to another safely and securely. Moreover, this is not possible without cloud-based applications and services. Cloud computing in healthcare has been viewed with some caution so far, due to security concerns surrounding highly sensitive patient information and, in many cases, compliance requirements.

Worldwide trends in the healthcare sector that have a bearing on mobile Health can be summarized as follows [3]:

$\checkmark$ there is an increased focus on prevention rather than cure;

\ EMR (Electronic Medical Records) are planned, but their popularity is still low;

^ "mobile" is not yet factored as a separate element of health budgets.

This shows that healthcare transformation will continue to focus on cost reduction and personalization. The customer model is becoming increasingly personalized (via biology and services), necessitating the ability to test the effectiveness of personalized treatments and services. Increased consumerism and competition will create a transparent, value-conscience market requiring readily available cost and quality information. The need for affordability will demand new technology and innovative solutions to drive down labor costs, significantly changing standard provider-person and community interactions

\section{Global trends}

Turning to information services and mobile devices is becoming a real trend for both patients and medical professionals. More than $80 \%$ of practicing physicians worldwide use mobile devices such as smartphones and tablets, along with various types of medical applications in these devices. Imagers are often adopted earlier than other innovation technologies, and radiologists have been quick to adopt mobile devices, for both personal and professional use [4]. More variety in mobile devices will soon mean that healthcare programs using mobile technology may become common. Global mobile health revenue will increase nearly six-fold to $\$ 23$ billion by 2017. Monitoring services and applications are expected to represent $65 \%$ of the market in 2017 , driven primarily by the rapidly aging population in developed countries and the high levels of chronic disease in emerging markets. PwC experts estimate that mobile-enabled monitoring services, like those offered for chronic disease management, will make up $65 \%$ of the worldwide mobile Healthcare market and account for $\$ 15$ billion of revenue by 2017. New technology is not enough. Widespread adoption of mHealth will require changes in the behavior of actors who are trying to protect their interests [5].

A survey carried out by Accenture shows that patients are embracing eHealth, but still want to have face-toface contact with doctors, though $76 \%$ of patients say the use of technology to manage their health has the potential to improve their health [6]. The use of mobile technologies within the health sector can be divided into several categories. These include: education, monitoring, staff tagging, asset tracking, tailor-made networks for hospitals and healthcare buildings, protection of healthcare workers during home visits, mobile applications, electronic medical records and mobile smartphone applications.

According to MobiHealthNews research [7], more than 15,000 consumer health apps were available in Apple's AppStore at the end of 2015. Consumer health apps focus on general health and wellness; new apps are being developed for informational purposes and not medical diagnosis. The number of people downloading fitness and healthcare applications is increasing. These include a growing band of iPhone applications developed by big pharma, such as Pfizer (with "Robitussin Relief Finder" and "Novartis Kick Smoking"), Sanofi-Aventis and a number of other companies.

New developments in labels include QR code technology, whereby manufacturers can track their prod- 
uct more effectively or consumers can download more information on the product or related products using a mobile device such as a smartphone or tablet.

EHR (Electronic Health Records system) is believed to be of great benefit to the mobile health sector of the future. However, in practice, their implementation is complex and expensive, and adoption on a global scale is low. The advantages of digital health records are that all medical records are centralized, making them available to care providers, thereby enabling quicker diagnosis and treatment. The difficulties of implementation include the fact that universally most health practices are too small to bear the costs of implementing electronic health records.

The concept behind the PHR (Personal Health Record) is that medical records are stored by a third party provider so that they can be accessible in whole or in part by healthcare professionals as and when needed. Ultimately though, mobile PHR systems represent the potential for significant changes in how medical data are stored and used. PHRs also represent a change in the "ownership" of health information - from the medical institution, or health authority, to the individual, who is thereby empowered. Eventually, the argument goes, the "cure" is replaced by continuous monitoring before any cure is needed.

The latest trend also worth mentioning in worldwide mHealth development is the active use of mHealth knowledge to integrate the traditional patient anamnesis data and the results of genetic research with further penetration of research knowledge to pediatricians and regular medical institutions. However, this new mHealth format of medical data analysis and sharing has not gotten much recognition in Russia so far.

\section{Healthcare in Russia}

\subsection{Healthcare structure overview}

The structure of the health system varies significantly from country to country. The Russian Federation has inherited its healthcare system from the Soviet Union. Under the Constitution, Russian citizens and permanent residents are entitled to free medical care. Structurally, this is carried out through a government-organized health insurance system referred to as the obligatory medical insurance scheme. The funding come from a healthcare tax imposed on all registered employers, who contribute the equivalent of just over $3 \%$ of each employee's income towards the healthcare fund. The remaining portion of the overall healthcare budget is pro- vided by the state. While the structure appears promising and compelling, the overall healthcare budget accounts for less than $4 \%$ of the country's GDP. Comparatively speaking, this is extremely low, given that an average industrial nation allocates between $8-11 \%$ of its GDP for healthcare.

Substantial effort has been made in recent years to boost the government fund allocation for the country's healthcare needs, however it will take considerable time before any significant results begin to show. The National Priority Project "Zdorovye" ("Health") was launched in 2006, with a budget of more than $\$ 12.85$ billion as part of the country's National Development Strategy 2020.

Computerization and implementation of IT services is one of the main goals of The National Priority Project. The IT Health Plan is synchronized with the overall program of health development to 2020 and is supposed to create a unified state information system in the health sector by 2020. By 2018, 95\% of citizens are expected to have an electronic medical record. With the growth of consumer spending and an increase in government funding in healthcare, the long-term outlook for Russian healthcare providers and medical manufacturers is very positive in Russia. In 2013, a remote record and scheduling system was established for visiting doctors (United Medical Information and Analytical System of Moscow - "EMIAS").

\subsection{Opportunities and barriers for mobile healthcare development}

In Russia, the proportion of the elderly in the general population ( $>65$ years) is growing at $\sim 2 \%$ a year while the overall population is shrinking at $\sim 0.3 \%$ year on year. Meanwhile, a rising incidence of chronic diseases (heart disease, stroke) indicates a steady shift in the disease profile of the country [8]. There is an increase in the volume of medical data considering the growth in the number of patients. The amount of patient information is usually huge. It includes images and scanned documents, family history, healthcare records, diagnoses, treatments, and studies on the individual. This information comes from multiple sources and there is no generic database storage system.

After initial disarray in the last months of 2008, the economic downturn provoked a shift to use of the Internet [9]. Considering the ubiquity of cellular networks, smartphones and similar devices, experts forecast growth in the role of mobile technology and online medicine in the near future in Russia. Moreover, this trend will contribute to the excess of sales of mobile devices 
over PCs. It should be noted that Russia is the fastest growing Internet economy in Europe and occupies one of the leading places in the world [10]. The Russian Internet web audience in the beginning of 2016 amounted to $66.5 \mathrm{M}$ users [11] ( $~ 57 \%$ of the Russian population) the biggest audience in Europe, coming 5th after China, the USA, Japan and India. Yet, there are still many adults and young people who would appreciate the social and economic benefits of mobile technology but are unable to access it. According to analysts, in Russia there are more than 700,000 physicians and about half of them are actively using computers. More than 150,000 of them regularly seek information on the Internet and use social networks to address professional issues and improve their skills.

Certain difficulties hinder the establishment of an upto-date healthcare system in Russia. A number of barriers need to be broken down in order to ensure proper communication between different stakeholders, connecting providers, physicians, patients, clinics, government, etc. Many Russian doctors are very concerned lest a patient get access to his entire medical history and will draw the wrong conclusions. In addition, such healthcare systems should suppose personal data protection.

Russian healthcare is striving to deliver better and more efficient healthcare, and technology is an increasingly important component of strategies for achieving this. However, concerns persist regarding security and transparency. Most cloud players in Russia do not explain how they implement their security measures. According to a Ponemon Institute study conducted in 2015 , the amount of fraud and data loss of medical information increased from $20 \%$ to $50 \%$ over the last five years globally [12]. The lack of transparency makes it difficult for enterprises to assess the security risks, and this significantly inhibits the adoption of this approach by large enterprises. The issue could be due to inadequate implementation of security measures or the lack of appreciation of concerns over security that large enterprises have; neither is acceptable for enterprises that want to deploy cloud for mission-critical applications.

Russia does not have the required regulatory base and needs to provide targeted government-backed funding with a specific focus on remote medical services and their integration into the existing healthcare programs. A major issue with data processing lies in the fact that patient information is stored in different objects, information is being lost or concealed through the fault of the patient or the doctor, while there are no personalized analytics.
According to the Association for the Development of Medical Information Systems [13], the key constraints on Russia are the lack of a clear government policy in the sphere of computer-based information systems for healthcare, a funding deficit at medical establishments, flagging industry and lack of communication with society. The status of electronic documents remains undefined, so that doctors are forced to keep records in both hard and soft copies.

Recently Russia adopted a national standard [14], requiring that the patient be provided with access to his/her electronic case record. However, the only legally valid document is still the hard copy of a medical record. At the same time, the law already recognizes the validity of an electronic signature, and the Health Ministry plans to lobby respective regulatory changes which would help validate any electronic document with an e-signature.

As key stakeholders in the mobile healthcare business, mobile operators face significant challenges, such as the lack of resource commitments from government and health authorities and an unclear idea of what mobile Health involves and what the key applications are. There might be a great potential for mobile operators, but considerable investment is also required. Currently no Russian mobile operator is willing to take social responsibility and invest proactively in development of the mobile healthcare market. According to J'son research [15], all three Russian telecom operators have already started in 2010-2012 to sign partnership agreements with health service providers. However, cellular operators are in waiting mode, looking forward to monetize the services on data transactions and SMS after the whole system is in place and generates revenue streams from mHealth.

\subsection{An overview of Russian solutions for mobile and digital healthcare}

Creating an integrated mobile solution with global growth potential and sufficient functionality, capable of attracting a large number of users, is not a myth but a reality. What is needed is to design the details of its integration with other existing information technologies and medical solutions, get the market potential evaluation right, find a user niche, as well as take into account all the applicable legal and security-related aspects.

The outstanding case of a proven current service in Russia is "Med@rchive" (www.Medarchiv.ru), a single platform for managing information on the patient's health, with a mobile application available for the pa- 
tient. The service provides access to a personal health card, which it is sufficient to get once. It makes it possible to preserve the history of an illness throughout the life of the patient. The service allows the accumulation of all the disparate data in a secure cloud storage, and provides a personal health services calendar, electronic interaction and consultation with doctors and drug and physiological monitoring

Other well-known projects in Russia include "SMSmame" (https://SMSmame.ru, an innovative educational service for pregnant women and young mothers), the mobile application "Donor" (https://Donor.ru, helps to know where and who requires blood donations), "Button of Life" or "Life Button" (https://knopka24.ru/, medical social panic button for the elderly, adults and children with disabilities).

One of mobile solutions that should be mentioned is the "Alive Heart and Activity Monitor" system (http:// www.alivetec.com/), developed by Alive Technologies (Australia) in cooperation with the Moscow State University. It is used for the diagnosis and monitoring of chronic heart disease. The Alive Heart Monitor is a wireless health monitoring system for screening, diagnosis and management of chronic diseases, and for consumer health and fitness.

The "Medicine" system from 1C (www.med.1c.ru) should be specifically noted. It has a very broad array of subsystems and client services. All solutions are built on 1C's unified technology platform. The 1C product line offers a specialized system of (food accounting and nutrition management program for medical and rehabilitation facilities that helps assess the appropriateness of energy values and nutrient levels and supports a natural level of consumption.

The National Research University Higher School of Economics is continuing to develop its Automatic System of Distance Healthcare Monitoring (ASDHM) (https://www.hse.ru/org/hse/iit/ithmc/). The goal of the ASDHM is to improve and extend the patient's quality of life for people with chronic diseases. Remote health monitoring technologies - devices that gather a patient's health data and relay it to a care provider - have been the subject of much study in recent years and this project is a first step on this direction.

The Russian Ministry of Health and Ministry of Social Development organize an annual competition for developments in Public Health called the "Best Medical Information System". Russian software developers have presented numerous solutions since 2011, but they were mostly aimed at supporting the workplace of doctors or organizing the paperwork of clinics. The results of analysis show that the majority of the solutions were directed at the B2B segment, while services to patients were very limited. Only about $10 \%$ of the healthcare systems are geared to online or mobile services with a real focus to patient's health.

In the near future, there are plans to launch a mobile service for drug identification in Russia. This service will provide citizens with information regarding any medicinal drugs within a few seconds. To use the system, the person should install on his mobile phone special software that can be downloaded free of charge. To obtain information about drug authenticity and medical uses a picture with a drug barcode should be scanned by the application

In 2016 emergency physicians working in rapid response cars are expected to be equipped with tablet computers integrated into the United Medical Information and Analytical System of Moscow ("EMIAS").

Talking about the prospects of mobile health development in Russia, three possible scenarios can be expected. The first is the development of mobile technologies from independent ecosystems (partnerships of digital startups, producers of mobile healthcare devices, commercial medical organizations, etc.) and their integration in the medical community and industry. This would be the obvious evolution of the industry in accordance with worldwide market trends. There would be the question of penetration of new mHealth services to the mass users. Without state subsidies such services might be quite expensive and not affordable for the majority of people. The state involvement is highly demanded.

The second scenario supposes we shall overcome all the barriers described above and develop a nationalbased program that includes personal healthcare medical recording and access to mHealth services on the national level. This cannot be expected in the shortterm.

The last possible scenario that should be mentioned is forcing the mHealth development by "Big Pharma" companies operating in Russia and worldwide. These companies are usually focused on cooperation with local medical institutions and associations, with constant communication with patients (via medical representatives and doctors) and might be also interested in medical research and mHealth development in order to provide customers with more personalized medical services and treatment, early diagnostics, bio technologies, smarter medical devices and services. 


\section{Conclusion}

In conclusion, it should be said that in Russia, despite many challenges, there are a lot of opportunities for the development of online and mobile healthcare applications. This should start with the establishment of a data repository (centralized or decentralized) for managing patients' health records and appointments with doctors and continue with advanced functions of personal health watch, systematic healthcare treatment, with patients becoming more advanced users of all available medical services in the country. There are still difficulties such as a lack of professional doctors and inability to use up-to-date and costly technologies and smartphones for patients, geographical distance and lack of $3 \mathrm{G} / \mathrm{Wi}$ Fi coverage in remote geographical districts. However, the trend is positive. Each year new technologies and systems appear, the awareness of citizens is increasing and the demand for such services is growing.

\section{References}

1. American Hospital Association (2014) Trendwatch Chartbook 2014. Trends affecting hospitals and health systems. Available at: http://www.aha. org/research/reports/tw/chartbook/2014/14chartbook.pdf (assessed 05 May 2016).

2. Tsvetkova L.A., Kuznetsov P.P., Kurakova N.G. (2014) Otsenka perspektiv razvitiya mobil'noy meditsiny - mHealth na osnovanii dannykh naukometricheskogo i patentnogo analiza [Evaluating perspectives of mobile healthcare development - mHealth based on scientific and patent analysis]. Doctor and Information Technologies, no. 4, pp. 68-79 (in Russian).

3. Cox A. (2010) Mobile healthcare opportunities monitoring, applications \& mHealth strategies 2010-2015. Juniper Research Whitepaper, no. 07.

4. Shrestha R.B. (2012) Mobility in healthcare and imaging: Challenges and opportunities. Applied Radiology, no. 9.

5. Levy D. (2014) Emerging mHealth: Paths for growth // PwC. Available at: https://www.pwc.com/gx/en/healthcare/mhealth/assets/pwc-emerging-mhealth-full.pdf (assessed 05 May 2016)

6. Safavi K., Ratli R. (2015) Healthcare IT Vision: Top5 eHealth Trends // Accenture. Available at: https://www.accenture.com/ acnmedia/ Accenture/Conversion-Assets/Microsites/Documents20/Accenture-Healthcare-Technology-Vision-2015-Infographic.pdf (accessed 05 May 2016).

7. Pai A. (2013) Flurry: Millennials use health and fitness apps more than other age groups. Available at: http://mobihealthnews.com/23117/millennials-use-health-and-fitness-apps-more-than-other-age-groups (accessed 05 May 2016).

8. Varlamova M.A, Sinyavskaya O.V. (2015) Portret pozhilogo naseleniya Rossii [Elderly people portrait in Russia]. Demoscop Weekly, no. 627628. Available at: http://www.demoscope.ru/weekly/2015/0627/demoscope627.pdf (accessed 05 May 2016) (in Russian).

9. Komissarova T.A., Andreas F. (2012) The impact of market reforms and economic conditions on marketing in Russia. International Studies of Management \& Organization, vol. 41, no. 4, pp. 51-64.

10. Grebennikov S., Logunova O., Petukhova S., et al. (2016) Ekonomika Runeta: Issledovanie ekonomiki rynka Internet-servisov i kontenta v Rossii 2014-2015 [Economy of Runet. Research of economy of Internet services and content market in Russia 2014-2015]. Available at: https:// www.hse.ru/data/2015/12/16/1134402660/RUNET15_Booklet_A4_PREVIEW\%20\%25281\%2529.pdf (accessed 05.05.2016) (in Russian).

11. Rozhkova A., Borisova S.,Zolotukhina T. (2015) Internet v Rossii: Analiticheskiy byulleten' [Internet in Russia: Analytical bulletin]. Issue 52. Winter 2015-2016. Moscow: InFOM (in Russian).

12. Korolov M. (2016) Meditsinskie dannye stali pokhishchat' chashche [Medical data is stolen more often]. Open Systems. Available at: http:// www.osp.ru/news/articles/2016/20/13049283/ (accessed 16 May 2016).

13. Sheyan I. (2014) Vybor sdelan [The choice is done]. Computerworld Russia, no. 10, p. 6 (in Russian).

14. GOST R 52636-2006: Elektronnaya istoriya bolezni. Obshchie polozheniya [Electronic healthcare record. Fundamentals]. Available at: http:// www.gostedu.ru/385.html (accessed 05 May 2016) (in Russian).

15. J'son \& Partners Management Consultancy (2013) Rynokmobil'noymeditsinyv Rossii ivmire:osnovnye tendentsii iprognozy [M-Health market in Russia and worldwide: main tendencies and forecasts]. Available at: http://www.json.ru/poleznye_materialy/free_market_watches/analytics /rynok mobilnoj mediciny v rossii_i_v mire osnovnye tendencii i prognozy/ (accessed 05 May 2016).

\section{Мобильное здравоохранение: Перспективы в России}

\section{С.М. Авдошин}

кандидат технических наук, профессор, руководитель департамента программной инженерии Национальный исследовательский университет «Высшая школа экономики»

Адрес: 101000, г. Москва, ул. Мясницкая, д. 20

E-mail: savdoshin@hse.ru

\section{Е.Ю. Песоцкая}

кандидат экономических наук, доцент департамента программной инженерии

Национальный исследовательский университет «Высшая школа экономики»

Адрес: 101000, г. Москва, ул. Мясницкая, д. 20

E-mail: epesotskaya@hse.ru 


\begin{abstract}
Аннотация
В статье рассматривается возможность использования мобильных технологий и сервисов в сфере здравоохранения, а также потенциал их развития в России. В рамках исследования проанализированы текущие глобальные тренды с изучением отдельных примеров решений в области мобильного здравоохранения. Проанализированы этапы формирования российской государственной медицинской системы, для того, чтобы понять основные этапы становления, достижения и сложности при формировании системы, такие как безопасность, доступность и функциональность. Рассмотрены основные барьеры и препятствия по развитию среды мобильного и электронного здравоохранения в России, чтобы понять перспективы мобильного здравоохранения. Принимая во внимание то, что информационные технологии играют крайне важную роль в области медицины, проведен анализ существующих информационных систем и разработок, рассмотрены несколько примеров систем. В итоге предложены три различных сценария дальнейшего развития мобильного здравоохранения в России. При формировании сценариев учтены как существующие барьеры в области здравоохранения в России, так и основные мировые тренды - такие как, например, персонализация сервисов или сокращение затрат на медицинские услуги.
\end{abstract}

Ключевые слова: система здравоохранения, мобильное здравоохранение, информационные системы диагностики здоровья, персонифицированная электронная медицинская карта, медицинская информационная система, мобильные услуги и сервисы, информационные технологии.

Цитирование: Avdoshin S.M., Pesotskaya E.Yu. Mobile healthcare: Perspectives in Russia // Business Informatics. 2016. No. 3 (37). P. 38-44. DOI: 10.17323/1998-0663.2016.3.38.44.

\title{
Литература
}

1. Trendwatch Chartbook 2014. Trends affecting hospitals and health systems // American Hospital Association. [Электронный ресурс]: http://www.aha.org/research/reports/tw/chartbook/2014/14chartbook.pdf (дата обращения 05.05.2016).

2. Цветкова Л.А., Кузнецов П.П., Куракова Н.Г. Оценка перспектив развития мобильной медицины - mHеalth на основании данных наукометрического и патентного анализа // Врач и информационные технологии. 2014. № 4. С. $68-79$.

3. Cox A. Mobile healthcare opportunities monitoring, applications \& mHealth strategies 2010-2015 // Juniper Research Whitepaper. 2010. No. 07 .

4. Shrestha R.B. Mobility in healthcare and imaging: Challenges and opportunities // Applied Radiology. 2012. No. 9.

5. Levy D. Emerging mHealth: Paths for growth // PwC. [Электронный pecypc]: https://www.pwc.com/gx/en/healthcare/mhealth/assets/ pwc-emerging-mhealth-full.pdf (дата обращения 05.05.2016).

6. Safavi K., Ratli R. Healthcare IT Vision: Top5 eHealth Trends // Accenture. [Электронный pecypc]: https://www.accenture.com/ _acnmedia/Accenture/Conversion-Assets/Microsites/Documents20/Accenture-Healthcare-Technology-Vision-2015-Infographic.pdf (дата обрашения 05.05.2016).

7. Pai A. Flurry: Millennials use health and fitness apps more than other age groups. [Электронный pecypc]: http://mobihealthnews. com/23117/millennials-use-health-and-fitness-apps-more-than-other-age-groups (дата обращения 05.05.2016).

8. Варламова M.A., Синявская О.В. Портрет пожилого населения России // Демоскоп Weekly. 2015. № 627-628. [Электронный pecypc]: http://www.demoscope.ru/weekly/2015/0627/demoscope627.pdf (дата обращения 05.05.2016).

9. Komissarova T.A., Andreas F. The impact of market reforms and economic conditions on marketing in Russia // International Studies of Management \& Organization. 2012. Vol. 41, no. 4. P. 51-64.

10. Экономика Рунета: Исследование экономики рынка Интернет-сервисов и контента в России 2014-2015 / С. Гребенников и [др.] // РАЭК, НИУ ВШЭ. [Электронный ресурс]: https://www.hse.ru/data/2015/12/16/1134402660/RUNET15_Booklet_A4_ PREVIEW\%20\%25281\%2529.pdf (дата обращения 05.05.2016).

11. Рожкова А., Борисова С., Золотухина Т. Интернет в России: Аналитический бюллетень. Выпуск 52. Зима $2015-2016$. М.: ИнФОМ, 2015.

12. Королов М. Медицинские данные стали похищать чаще // Открытые системы. 2016. [Электронный pecypc]: http://www.osp.ru/ news/articles/2016/20/13049283/ (дата обращения 16.05.2016).

13. Шеян И. Выбор сделан // Computerworld Россия. 2014. № 10. С. 6.

14. ГОСТ Р 52636-2006: Электронная история болезни. Общие положения. [Электронный pecypc]: http://www.gostedu.ru/385.html (дата обрашения 05.05.2016).

15. Рынок мобильной медицины в России и в мире: основные тенденции и прогнозы // J'son \& Partners Management Consultancy. Июль 2013. [Электронный pecypc]: http://www.json.ru/poleznye_materialy/free_market_watches/analytics/rynok_mobilnoj_ mediciny_v_rossii_i_v_mire_osnovnye_tendencii_i_prognozy/ (дата обращения 05.05.2016). 